\title{
Bivalency of plasminogen monoclonal antibodies is required for plasminogen bridging to fibrin and enhanced plasmin formation
}

\author{
Miguel Dominguez ${ }^{\mathrm{a}, 1}$, Ramón Montes ${ }^{\mathrm{b}}$, José Antonio Páramo ${ }^{\mathrm{b}}$, Eduardo Anglés-Cano ${ }^{\mathrm{a}, *}$ \\ a Plasminogen Activation in Cardiovascular Remodelling, Institut National de la Santé et de la Recherche Médicale, INSERM U460, \\ UFR de Médecine Xavier Bichat, 16 rue Henri Huchard-BP 416, 75870 Paris Cedex 18, France \\ ${ }^{\mathrm{b}}$ Facultad de Medicina, Universidad de Navarra, Pamplona, Spain
}

Received 8 January 2002; received in revised form 3 May 2002; accepted 24 May 2002

\begin{abstract}
Binding of plasminogen to fibrin and cell surfaces is essential for fibrinolysis and pericellular proteolysis. We used surface plasmon resonance and enzyme kinetic analyses to study the effect of two mAbs (A10.2, CPL15) on plasminogen binding and activation at fibrin surfaces. A10.2 is directed against the lysine-binding site (LBS) of kringle 4, whereas CPL15 recognises a region in kringle 1 outside the LBS. In the presence of CPL15 and A10.2 mAbs, binding of plasminogen $\left(K_{\mathrm{d}}=1.16 \pm 0.22 \mu \mathrm{mol} / \mathrm{l}\right)$ to fibrin was characterised by a mAb concentration-dependent bell-shaped isotherm. A progressive increase in the concentration of mAbs at the surface was also detected, and reached a plateau corresponding to the maximum of plasminogen bound. These data indicated that at low mAb concentration, bivalent plasminogen $-\mathrm{mAb}$ - plasminogen ternary complexes are formed, whereas at high $\mathrm{mAb}$ concentration, a progressive shift to monovalent plasminogen $-\mathrm{mAb}$ binary complexes is observed. Plasmin formation in the presence of mAbs followed a similar bell-shaped profile. Monovalent Fab fragments of mAb A10.2 showed no effect on the binding of plasminogen, confirming the notion that a bivalent mAb interaction is essential to increase plasminogen binding and activation at the surface of fibrin.
\end{abstract}

(C) 2002 Elsevier Science B.V. All rights reserved.

Keywords: mAb bivalency; Plasminogen binding; Plasminogen activation; Biosensor analysis; Fibrin surface; Kringle domain

\section{Introduction}

Native plasminogen is a single-chain polypeptide of 791 amino acids consisting of NH2-terminal glutamic acid followed by a tandem of five domains called kringle, a sequence containing the cleavage site (Arg561-Va1562) and a serine protease domain [1]. Plasminogen is the inactive precursor of the protease plasmin, which plays a pivotal role in fibrinolysis, cell migration and tissue remodeling [2]. Plasminogen binds to fibrin blood cells (neutrophils, monocytes) [3-5] and vascular cells [6] through the lysine-binding sites (LBSs) of kringle-1 and kringle 4 domains [7]. These interactions markedly increase the susceptibility of plasminogen to proteolytic activation by tissue- (t-PA) and

\footnotetext{
* Corresponding author. Tel.: +33-1-44-85-61-50; fax: +33-1-44-85-61-56.

E-mail address: angles@infobiogen.fr (E. Anglés-Cano).

${ }^{1}$ Present address: Departamento de Ciencias Basicas, Centro Universitario de Ciencias de la Salud, Universidad de Guadalajara, Jalisco, Mexico.
}

urokinase-type plasminogen activators on fibrin and cell surfaces, respectively $[8,9]$. This process is mainly regulated by $\alpha_{2}$-antiplasmin and plasminogen activator inhibitor type 1. Other factors may, however, interfere with this mechanism. Among them, the lipoprotein $\mathrm{Lp}$ (a) [10], a highly atherogenic lipoprotein particle, which possesses multiple copies of plasminogen-like kringle 4 in its apolipoprotein(a), apo(a), moiety [11]. Lp(a) inhibits plasmin formation by competing with plasminogen for binding sites on fibrin and cell surfaces $[12,13]$. On the other hand, it has been demonstrated that the interaction of monoclonal antibodies with the low- or high-affinity LBSs of plasminogen may result in conformational changes yielding the plasminogen more susceptible to activation by plasminogen activators $[14,15]$. It is conceivable, however, that an additional mechanism intrinsic to antibody structure, antibody bivalency, may explain the increase in plasmin formation. A number of reports have shown for instance that antibody bivalency is an absolute requirement for the enhanced binding of prothrombin and 32 -glycoprotein I to phospholipids [16-22]. We hypothesise that mAbs directed against 
plasminogen may increase its binding to fibrin through a similar mechanism. The availability of the monoclonal antibodies A10.2 that interacts with the LBS of plasminogen kringle 4 [23] and CPL15 that recognises plasminogen kringle 1 [24], prompted us to investigate their effect on plasminogen binding under static and flow conditions using surface plasmon resonance (SPR) analysis. In the present work, we show that these mAbs enhance plasmin formation and fibrinolysis through the formation of bivalent plasminogen $-\mathrm{mAb}-$ plasminogen complexes that result in increased plasminogen binding to fibrin surfaces.

\section{Materials and methods}

\subsection{Reagents}

All of the chemicals used were of the best reagent grade commercially available. Other products were purchased from the following sources. Bovine serum albumin (BSA) from Eurobio (Les Ulis, France); (methylmalonyl)hydroxyprolylarginine- $p$-nitroanilide (CBS 0065) from Diagnostica Stago (Asnières, France); 6-aminohexanoic acid (6-Ahx) and papain from Sigma (St. Louis, MO, USA); nitrocellulose sheets from Sartorius (Palaiseau, France). Composition of buffers: buffer A, $50 \mathrm{mmol} / 1$ sodium phosphate, $\mathrm{pH} 7.4$, $80 \mathrm{mmol} / 1 \mathrm{NaCl}, 0.01 \%$ Tween 20 , and $0.01 \% \mathrm{NaN}_{3}$; assay buffer, buffer A containing $2 \mathrm{mg}$ of BSA $/ \mathrm{ml}$. HBS buffer for Biacore experiments consisted of $10 \mathrm{mmol} / \mathrm{l}$ Hepes, $\mathrm{pH}$ 7.4, $150 \mathrm{mmol} / \mathrm{l} \mathrm{NaCl}$, and $0.05 \%(\mathrm{v} / \mathrm{v})$ surfactant P20.

\subsection{Protein purification and radioiodination}

Fibrinogen was purified from fresh-frozen human plasma supplemented with proteinase inhibitors $(100$ k.i.u./ml aprotinin, $2 \mathrm{mmol} / \mathrm{l}$ phenylmethysulphonyl fluoride PMSF, 1 $\mu \mathrm{mol} / \mathrm{l}$ H-D-Phe-Pro-Arg-CH ${ }_{2} \mathrm{CI}, 200 \mathrm{mmol} / \mathrm{l}$ 6-Ahx, 10 $\mu \mathrm{mol} / \mathrm{l} p$-nitrophenyl- $p^{\prime}$-guanidinobenzoate, and $4 \mathrm{mmol} / \mathrm{l}$ benzamidine, final concentrations), as previously described [25] with minor modifications [26]. In brief, the procedure included two glycine precipitations of proteins remaining in the soluble phase of plasma precipitated twice with $\mathrm{BaSO}_{4}$, followed by chromatography on a Sepharose 6B column in $50 \mathrm{mmol} / \mathrm{l}$ phosphate buffer, $\mathrm{pH} 7.4$, containing $0.5 \mathrm{~mol} / \mathrm{l}$ $\mathrm{NaCl}, 2 \mathrm{mmol} / \mathrm{l}$ EDTA and all aforementioned inhibitors except 6-Ahx. Further purification was obtained by affinity chromatography on lysine-Sepharose 4B, gelatine-Ultrogel and organomercurial agarose. Fibrinogen was concentrated by precipitation with glycine $(0.16 \mathrm{~g} / \mathrm{l})$, extensively dialysed against $0.1 \mathrm{~mol} / 1$ phosphate buffer, $\mathrm{pH} 7.4$, containing 0.3 $\mathrm{mol} / \mathrm{l} \mathrm{NaCl}$, separated into aliquots $(12 \mathrm{mg} / \mathrm{ml})$ and stored at $-80{ }^{\circ} \mathrm{C}$. The purified fibrinogen was free from von Willebrand factor, plasminogen, fibronectin and factor XIII as determined with enzyme-linked immunosorbent assays specific for these proteins; the absence of plasminogen or plasmin was confirmed by incubating for $72 \mathrm{~h}$ at $37{ }^{\circ} \mathrm{C}$ fibrin-agar plates prepared with the purified product supplemented or not with t-PA. Fibrinogen was more than $98 \%$ clottable and appeared homogeneous by SDS-polyacrylamide gel electrophoresis. Plasminogen was purified from fresh-frozen human plasma supplemented with proteinase inhibitors as described [27]. Elastase-derived plasminogen fragments kringle $1+2+3$, and kringle 4 were prepared according to Sottrup-Jensen et al. [28] with minor modifications [29]. Human recombinant apo(a) was prepared and isolated as described [23]. Human $\alpha$-thrombin purified as previously described [30] was kindly provided by M.C. Gullin (Faculté X. Bichat, University of Paris). Protein concentration was estimated by measuring the absorbance at $280 \mathrm{~nm}$ and using relative molecular masses and extinction coefficients $\left(\varepsilon_{280}^{1} \mathrm{mg} / \mathrm{mm}, \mathrm{cm}\right)$ of 340000 and 15.1 for fibrinogen [31], 93000 and 16.8 for plasminogen [32], 10000 and 3.1 for kringle 4, 35000 and 8.08 for kringle $1+2+3,36500$ and 1.83 for $\alpha$-thrombin [33]. Human t-PA ( $>95 \%$ single-chain) purified from Bowes melanoma cellconditioned medium on immobilized monoclonal antibody anti-t-PA was from Biopool (Uppsala, Sweden); it had a specific activity of $680000 \mathrm{IU} / \mathrm{mg}$.

Plasminogen was radioiodinated with $\mathrm{Na}\left[{ }^{125} \mathrm{I}\right]$ using the lodogen ${ }^{\mathrm{TM}}$ method [34], an iodination time of 4 min at $4{ }^{\circ} \mathrm{C}$ and removal of free ${ }^{125} \mathrm{I}$ by molecular sieving on a PD-10 Sephadex column (Pharmacia, Uppsala, Sweden). The specific radioactivity obtained was $3 \mathrm{nCi} / \mathrm{ng}$.

\subsection{Monoclonal antibodies}

Murine monoclonal antibodies A10.2 and CPL15 were prepared as previously described using conventional hybridoma technology. MAb A10.2 is an $\mathrm{IgG}_{1}$ directed against the LBS of plasminogen kringle 4 and plasminogen-like KIV10 of apo(a) that was raised by immunization of $\mathrm{BALB} / \mathrm{c}$ mice with recombinant apo(a) [23]. CPL15 is an $\mathrm{IgG}_{1} \mathrm{mAb}$ directed against the kringle 1 of plasminogen as indicated by its reactivity against the plasminogen fragment $\mathrm{K} 1+2+3$ and plasmin $-\alpha_{2}$-antiplasmin complexes [24]. Y18, an IgM $\mathrm{mAb}$ that recognises the A $\alpha$ stretch 1-51 of human fibrinogen [35], was kindly provided by Dr. W. Nieuwenhuizen (Gaubius Institut, Leyden, The Netherlands).

\subsection{Preparation of Fab fragments}

The IgG fraction of mAbs was isolated from a hollow fiber bioreactor supernatant by Hi-Trap r-protein-A sepharose (Pharmacia) affinity chromatography as described by Ey et al. [36], with minor modifications. The IgG $(20 \mathrm{mg})$ of $\mathrm{mAb}$ A10.2 was digested for $30 \mathrm{~min}$ at $37{ }^{\circ} \mathrm{C}$ with papain (mass ratio papain/IgG, $1: 100$ ) in $50 \mathrm{mmol} / 1$ phosphate buffer, $\mathrm{pH} 7.4$, containing $50 \mathrm{mmol} / \mathrm{l}$ cystein. Before starting the reaction, the mixture was flushed with nitrogen to prevent cystein oxidation. The reaction was terminated by adding $50 \mathrm{mmol} / 1$ iodoacetamide. The mixture was then dialysed against $100 \mathrm{mmol} / \mathrm{l}$ sodium citrate buffer, $\mathrm{pH} 5$. 
The digested material was chromatographed on a Hi-Trap rprotein-A sepharose, which retained most of the Fc fragments and undigested IgG. Further purification of the flow through protein peak was obtained by gel filtration on an HR-Sephadex 200 column (Pharmacia) equilibrated with the same buffer. The purified Fab migrated as a single protein band of 50000 relative molecular mass in non-reducing $7.5 \%$ polyacrylamide gels.

\subsection{SPR analyses}

Interactions between plasminogen, fibrin and the mAbs were investigated by real-time biospecific analysis based on SPR measurements using a BIAcore ${ }^{\circledR} 2000$ system and reagents from Biacore (Uppsala, Sweden), including the amine coupling kit (NHS, $N$-hydroxysuccinimide; EDC, $N$ ethyl- $N^{\prime}$-(3-dimethyllaminopropyl) carbodiimide hydrochloride; ethanolamine hydrochloride), an immunosorbent purified rabbit IgG directed against mouse Fc (RamFc) and sensor chips CM5 and pioneer $\mathrm{C} 1$. The change in refractive index induced by the association and dissociation of proteins interacting with the sensor surface as a function of time is expressed in resonance units (RU) [37]. A relationship in which $1000 \mathrm{RU}$ corresponds approximately to a surface mass change of $1 \mathrm{ng}$ protein $/ \mathrm{mm}^{2}$ has been established [38] that may reasonably be considered to apply to all proteins as they display similar specific refractive index increments. All experiments were performed at $25{ }^{\circ} \mathrm{C}$ with a flow rate of 10 $\mu 1 /$ min unless otherwise indicated.

\subsubsection{Determination of affinity of $m A b s$ for plasminogen in fluid phase}

Interaction of plasminogen with immobilised mAbs A10.2 and CPL15 was determined using a CM5-RamFc sensor chip prepared as described [39]. Briefly, activation of the CM5 sensor chip as indicated above was followed by immobilisation of the RamFc $(70 \mu \mathrm{l}$ at $40 \mu \mathrm{g} / \mathrm{ml}$ in 10 $\mathrm{mmol} / 1$ sodium acetate, $\mathrm{pH} 4.8$ ) and blocking of remaining unreacted active NHS-ester groups with $1 \mathrm{~mol} / 1$ ethanolamine hydrochloride. Typical immobilisations yielded 13500 RU corresponding to $13.5 \mathrm{ng}\left(90 \mathrm{fmol} / \mathrm{mm}^{2}\right)$ of RamFc bound to the biosensor surface. An analytical immunocapture cycle consisted of injection of mAbs (1 $\mu \mathrm{g} / \mathrm{ml}$ ) followed by a $10-\mu \mathrm{l}$ injection of plasminogen or its fragments $(0-500 \mathrm{nmol} / \mathrm{l})$, buffer flow for dissociation, and regeneration of the surface with $10 \mu \mathrm{l} 50 \mathrm{mmol} / \mathrm{l} \mathrm{HCl}$. The amount bound (RU) at equilibrium was recorded and fitted to the Langmuir equation as a function of plasminogen concentration to calculate affinity constant $\left(K_{\mathrm{d}}\right)$ and maximum bound $\left(B_{\max }\right)$. Affinity constants were also calculated from kinetic data.

\subsubsection{Preparation of fibrin sensor chip surfaces}

Fibrinogen was first immobilised on $\mathrm{C} 1$ sensor chips as follows. The sensor surface was activated with a mixture of NHS/EDC according to the manufacturer's instructions. The
C1 sensor chip is a carboxymethylated flat surface with no dextran matrix that was further treated with $20 \mathrm{mmol} / \mathrm{l} \mathrm{1,6-}$ diaminehexane followed by $2.5 \%$ polymerised glutaraldehyde used as linker/spacer. Fibrinogen $(70 \mu \mathrm{l}$ at $50 \mu \mathrm{g} / \mathrm{ml}$ in $10 \mathrm{mmol} / 1$ sodium acetate, $\mathrm{pH} 5.5$ ) was then covalently coupled onto three flow cells via primary amino groups at a flow rate of $10 \mu \mathrm{l} / \mathrm{min}$ at $25^{\circ} \mathrm{C}$. Unreacted amino groups in fibrinogen-coated cells were inactivated by injecting $40 \mu \mathrm{l}$ of $1 \mathrm{~mol} / \mathrm{l}$ ethanolamine hydrochloride. The remaining uncoated flow cell was blocked with ethanolamine as above with no fibrinogen added, to serve as a control for the contribution of the bulk refractive index. The SPR response for the immobilisation of fibrinogen was $17000 \pm 1000 \mathrm{RU}$ $\left(50 \pm 3 \mathrm{fmol} / \mathrm{mm}^{2}\right)$ at the concentration used.

On-chip digestion of immobilised fibrinogen was performed by injecting active $\alpha$-thrombin $(100 \mathrm{nmol} / \mathrm{l})$ at a flow of $2 \mu \mathrm{l} / \mathrm{min}$ for $20 \mathrm{~min}$. The cleavage of fibrinopeptide A by $\alpha$-thrombin was verified by measuring the binding of Y18, a monoclonal antibody directed against an epitope comprised in the A $\alpha$ 1-51 sequence of human fibrinogen [35]. A resonance response of $\sim 13700 \mathrm{RU}$ was finally obtained equivalent to $\sim 43 \mathrm{pmol}$ of immobilised fibrin per square millimeter.

\subsubsection{Interactions between plasminogen, monoclonal antibodies and fibrin surfaces}

The fibrin sensor chip was equilibrated with $10 \mathrm{mmol} / \mathrm{l}$ Hepes, pH 7.5, $0.15 \mathrm{~mol} / 1 \mathrm{NaCl}, 0.003 \%$ Tween 20 for several hours at $5 \mu \mathrm{l} / \mathrm{min}$ before collection of experimental data. Functionality of the fibrin sensor chip was first assessed by measuring the specific binding of plasminogen (0.01-20 $\mu \mathrm{mol} / \mathrm{l})$, or r-apo(a) $(0.007-1 \mu \mathrm{mol} / \mathrm{l})$ previously treated with $1 \mu \mathrm{mol} / \mathrm{l} \mathrm{H}-\mathrm{D}-\mathrm{Val}-\mathrm{Pro}-\mathrm{Lys}-\mathrm{CH}_{2} \mathrm{Cl}$ (VPK). A $10-\mu \mathrm{l}$ volume of the indicated concentrations was injected at a flow rate of $10 \mu \mathrm{l} / \mathrm{min}$. The fibrin surface was regenerated after each binding interaction with $0.2 \mathrm{~mol} / 1 \mathrm{6}$-Ahx in HBS at a flow rate of $30 \mu \mathrm{l} / \mathrm{min}$ for $30 \mathrm{~s}$. Specificity of the binding was determined by injecting selected concentrations of either plasminogen or apo(a) previously incubated with varying concentrations of 6-Ahx. The reciprocal of the measured response (1/RU) was then plotted against the concentration of 6-Ahx and the inhibition constant calculated at the intersection of the linear regression analysis for each analyte concentration. To investigate the effect of mAbs on the binding of plasminogen to fibrin, a $25-\mathrm{nmol} /$ 1 final plasminogen concentration and $0-250 \mathrm{nmol} / 1 \mathrm{mAbs}$ $\mathrm{IgG}$ or $\mathrm{Fab}$ fragment were incubated for $15 \mathrm{~min}$ at $22{ }^{\circ} \mathrm{C}$ and then injected onto the fibrin sensor chip. Elution of plasminogen-mAbs complexes was performed with 0.2 mol/1 6-Ahx as indicated above. The response for the reference uncoated flow cell was subtracted from that of the coated cells to correct for bulk refractive index changes, non-specific binding, and instrument drift. The flow cells with immobilised fibrin showed good stability and no significant decrease in bound fibrin was observed during the course of the experiments. 


\subsection{Effect of $m A$ bs on plasmin formation at the surface of fibrin}

Fibrin surfaces were prepared as described [27]. Briefly, fibrinogen was covalently bound to stable polyglutaraldehyde derivatives and was transformed into a fibrin surface by treatment with $\alpha$-thrombin. This procedure is similar to the one used for the preparation of fibrin surfaces on $\mathrm{C} 1$ sensor chips except for the use of multi-well polyvynil chloride plates as solid support. The activation of plasminogen by t-PA on these fibrin plates was performed as indicated elsewhere [40], with minor modifications. Briefly, a solid-phase fibrin plate was washed three times with binding buffer, and $50 \mu \mathrm{l}$ per well of the same buffer containing $100 \mathrm{IU} / \mathrm{ml} \mathrm{t}$-PA was incubated for $1 \mathrm{~h}$ at 37 ${ }^{\circ} \mathrm{C}$. The plate was then washed twice with assay buffer to remove unbound proteins, and the activation was started by adding $50 \mu \mathrm{l}$ per well of plasminogen $(150 \mathrm{nmol} / \mathrm{l})$ alone or supplemented with mAbs A10.2 or CPL15 IgG or Fab fragment at three different concentrations. A mouse myeloma IgG (P3X63) was used as a control. To quantitate the amount of fibrin-bound plasmin(ogen), experiments were performed in the presence of a trace amount of ${ }^{125} \mathrm{I}$-Gluplasminogen (4-8 nmol/l, final concentration). The activation was performed in a series of three wells and was monitored at $37{ }^{\circ} \mathrm{C}$ for $1 \mathrm{~h}$. Every $15 \mathrm{~min}$, the reaction was stopped by removing the fluid phase and washing the wells with assay buffer. Fibrin-bound plasmin was then detected by measuring its amidolytic activity or counting the radioactivity as follows. A volume of $50 \mu \mathrm{l}$ of $1.5 \mathrm{mmol} /$ 1 CBS 0065 in assay buffer/well was added and the rate of $p$ nitroanilide hydrolysis was measured from the change in absorbance at a double-wavelength absorbance ratio $\left(A_{405} /\right.$ $\left.A_{490}\right)$ with a microtitration plate counter (MR 5000, Dynatech) equipped with a thermostatic device to maintain temperature at a constant $37{ }^{\circ} \mathrm{C}$. Since the substrate is added after washing off proteins in solution, the increase in absorbance at $405 \mathrm{~nm}$ is linear with time and the slope $\left(\Delta A_{405} / \mathrm{min}\right)$ proportional to the amount of plasmin generated during the activation period. Initial rates of $p$-nitroaniline release from CBS 0065 were therefore transformed into femtomoles of plasmin bound per well using the following equations.

$[$ plasmin $]=v\left[K_{\mathrm{m}}+[\mathrm{CBS} 0065] / K_{\mathrm{cat}}[\mathrm{CBS} 0065]\right.$

as described by Fleury et al. [41]. For that purpose, values of $A_{405 \mathrm{~nm}} /$ min were converted to moles per second using a molar extinction coefficient for $p$-nitroaniline of $9920 \mathrm{~mol}$ $1^{-1} \mathrm{~cm}^{-1}$ adapted to a $50-\mu 1 /$ well pathway, and the following values for the concentration of CBS $0065=0.75$ $\mathrm{mmol} / 1, K_{\mathrm{m}}=0.661 \mathrm{mmol} / 1$, and $K_{\mathrm{cat}}=25.42 \mathrm{~s}^{-1}$. At the end of the kinetic measurement, the plate was washed three times with assay buffer, and radioactivity in the wells counted in a gamma radiation counter. The total amount of plasmin(ogen) derivatives bound to fibrin was reported in picomoles of protein bound per well using the molar radioactiviy of the plasminogen activation solution.

In parallel experiments, the fibrin surface was probed with a peroxidase-conjugated goat anti-mouse IgG antibody (Dako, Denmark) to detect possible binding of the mAbs to the fibrin surface. A $1-\mathrm{mg} / \mathrm{ml}$ solution of 2,2' -azinobis 3ethyl-benzthiazoline-6 sulfonic acid (ABTS, Roche Pharmaceuticals, Germany) was used as a substrate for color development. The absorbance of the developing solution was measured at $A_{405} \mathrm{~nm}$.

\subsection{Analysis of SPR binding data}

For a bimolecular interaction between the immobilised ligand and the soluble analyte, the relative response of the optical biosensor at time $t$ is proportional to the amount of ligand/analyte complex formed. Since (1) the concentration of immobilised ligand (nanograms protein per square millimeter) is constant, and (2) the amount of complexes formed is a function of both the free solute concentration and the affinity of the interaction, a simple thermodynamic analysis can be used to characterize the adsorption phenomenon. To avoid the distortion error that is introduced by analysis of linearly transformed data, the results have been interpreted in terms of the simplest form of this relationship, the rectangular hyperbolic Langmuir adsorption equation for bimolecular single-site interactions at heterogeneous interfaces [42].

$R_{\mathrm{eq}}=\frac{R_{\max } K_{\mathrm{a}}}{1+K_{\mathrm{a}} L}+(b) L=\frac{R_{\max } L}{K_{\mathrm{d}}+L}+(b) L$

where $R_{\text {eq }}$, the SPR response, is a function of $L$, the solute concentration, $R_{\max }$ is the maximum SPR response for a flow cell that has its immobilised ligand fully saturated with analyte, and $K_{\mathrm{a}}$ and $K_{\mathrm{d}}$ the equilibrium and dissociation constants, respectively. $(b)$ is a proportionality constant representing nonspecific binding. A correct fit of data to this equation using non-linear regression analysis (Kalleidagraph software) allows quantitation of both the maximum bound $\left(B_{\max }\right)$ and the dissociation constants $K_{\mathrm{d}}=K_{\mathrm{a}}{ }^{-1}$. Response plateau values, obtained after binding has reached equilibrium, were plotted versus the concentration of analyte that were flowed into the sensor chip channels. If the simple Langmuir relationship fits correctly a plot of the measured response versus ligand concentration, then the binding interaction obeys a one-to-one binding model, and the kinetic constants can be determined using this model [43]. The theory of kinetic measurement of this interaction has been well established $[44,45]$. The evaluation of association $\left(K_{\text {on }}\right)$ and the dissociation $\left(K_{\text {off }}\right)$ rate constants was performed using fitting procedures in the BiaEval 3.0 program (Biacore) applying the 1:1 Langmuir binding model. Consistency of the data was examined by comparison of the equilibrium constants with the thermodynamic analysis using the Langmuir relationship. 


\section{Results}

\subsection{Biosensor analysis of specificity and affinity of $m A b s$ for plasminogen}

Plasminogen and its fragments at varying concentrations were flowed onto RamFc-immobilised mAbs and data were fitted to the Langmuir model assuming a 1:1 binding interaction. Results are shown in Table 1. A dissociation constant of $13 \pm 0.65$ and $32 \pm 0.15 \mathrm{nmol} / 1$ was calculated for A10.2 and CPL15 mAbs, respectively. These values were in good agreement with those obtained from kinetic data (not shown). In experiments performed with isolated elastase-derived plasminogen fragments, it was demonstrated that $\mathrm{mAb}$ CPL15 recognises an epitope present in fragment $\mathrm{K} 1+2+3\left(K_{\mathrm{d}}=5.8 \pm 0.5 \mathrm{nmol} / \mathrm{l}\right)$, whereas $\mathrm{mAb}$ A10.2 recognises the LBS of fragment K4 $\left(K_{\mathrm{d}}=5.6 \pm 0.6\right.$ $\mathrm{nmol} / \mathrm{l})$.

\subsection{Interactions between plasminogen and $m A b s$ on a fibrin sensor chip}

A fibrin surface sensor chip was used to examine the binding characteristics of plasminogen in the presence of mAbs A10.2 and CPL15 by SPR analysis. This technique was used because it detects adsorption of protein complexes onto a sensor chip surface in real time as a function of the concentration of one of the components. For this purpose, fibrinogen was immobilised onto $\mathrm{C} 1$ sensor chips and then transformed into fibrin by flowing active $\alpha$-thrombin. As digestion of fibrinogen immobilised on the sensor chip progressed, the resonance response gradually lowered (Fig. 1). The sensorgram thus obtained clearly differed from sensorgrams of simple analyte-ligand association. A marked decrease in the refractive index was observed as a function of time of $\alpha$-thrombin injection indicating loss of material, due to on-chip digestion. Fibrinogen to fibrin conversion, loss of fibrinopeptides, was verified by decrease in reactivity with $\mathrm{Y} 18$, a mAb that specifically recognises fibrinopeptide A in fibrinogen. Reactivity of mAb Y18 with the sensor chip was no longer detectable after five successive injections of $\alpha$-thrombin (Fig. 1, inset) indicating the formation of a fibrin monolayer. This surface was functionally characterised by measuring binding of proteins, plasminogen and a recombinant apo(a), known to specifically

Table 1

SPR binding affinity of plasminogen and its derivatives to mAbs

\begin{tabular}{llll}
\hline & Plasminogen & $\mathrm{K} 1+2+3$ & $\mathrm{~K} 4$ \\
\hline A10.2 & $13 \pm 0.65$ & - & $5.6 \pm 0.6$ \\
CPL15 & $32 \pm 0.5$ & $5.8 \pm 0.6$ & - \\
\hline
\end{tabular}

Dissociation constants $\left(K_{\mathrm{d}}, \mathrm{nmol} / \mathrm{l}\right)$ as calculated by nonlinear regression analysis in terms of the rectangular hyperbolic relationship (Fig. 2) between $\mathrm{mAb}$ immobilised on a rabbit anti-mouse Fc sensor chip and plasminogen or its elastase-derived fragments in the flowing solution. These values were in agreement with those calculated from kinetic data.

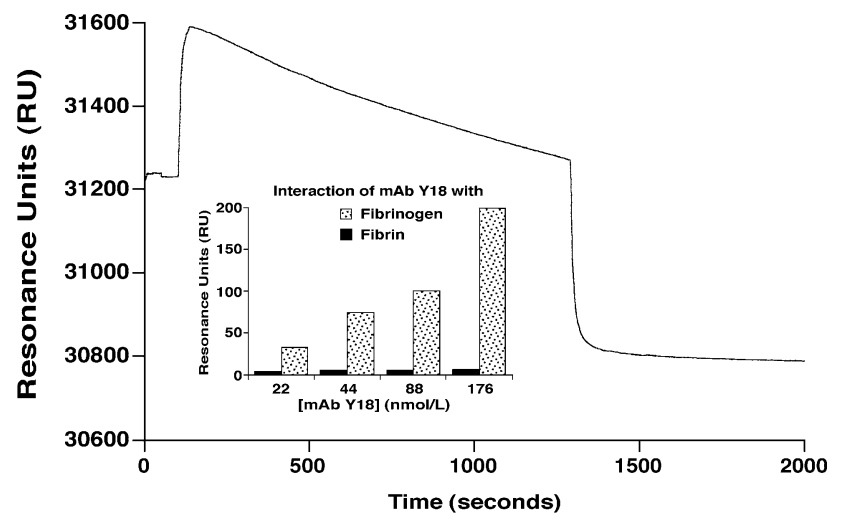

Fig. 1. On-chip fibrinogen to fibrin transformation with $\alpha$-thrombin. Fibrinogen was immobilized on a pioneer $\mathrm{C} 1$ sensor chip $(17000 \mathrm{RU}, \sim 50$ $\left.\mathrm{fmol} / \mathrm{mm}^{2}\right)$ using glutaraldehyde chemistry. Active $\alpha$-thrombin $(0.1 \mu \mathrm{mol} / \mathrm{l})$ was flowed on the immobilized fibrinogen at a flow rate of $2 \mu \mathrm{l} / \mathrm{min}$. The main figure shows a typical on-chip digestion sensorgram. The initial response gradually lowered with time of $\alpha$-thrombin delivery to the sensing flow cell. The decrease in the baseline resonance after the end of $\alpha$ thrombin injection $(31725 \rightarrow 30790)$ indicated that proteolytic conversion of fibrinogen to fibrin had occurred. Inset: Release of fibrinopeptide A by $\alpha$-thrombin as monitored with a monoclonal antibody (Y18) directed against the $A \alpha$ stretch 1-51 of human fibrinogen [35]. Bars represent the binding response of Y18 to immobilized fibrinogen before delivery of active $\alpha$-thrombin (open bars) and after five successive injections of active $\alpha$-thrombin (filled bars).

interact with fibrin through LBSs. These interactions reached saturation, were specifically inhibited by $6-\mathrm{Ahx}$ $\left[K_{\mathrm{i}}=0.112 \mathrm{mmol} / 1\right.$ for plasminogen and $K_{\mathrm{i}}=0.5 \mathrm{mmol} / 1$ for $\mathrm{r}$-apo(a)] and were characterised by single-site binding as indicated by plots of the binding response at equilibrium versus the concentration of analyte according to the Langmuir equation (Fig. 2). The dissociation constants calculated for plasminogen, $K_{\mathrm{d}}=1.16 \pm 0.22 \mu \mathrm{mol} / \mathrm{l}$, and for apo(a), $K_{\mathrm{d}}=54 \pm 5 \mathrm{nmol} / \mathrm{l}$, are in agreement with previously published data $[12,27,29]$ in which fibrin was immobilised on multi-well plates using polymerised glutaraldehyde as a linker. This procedure has been previously proven to result in a fibrin monolayer that mimics a fibrin clot surface with regard to plasminogen binding and activation in a static system $[27,40,41]$. The finding of similar results in polyglutaraldehyde-activated $\mathrm{C} 1$ sensor chips indicates that binding of plasminogen preceding its activation on fibrin in a static system and binding of plasminogen observed in real time under flow conditions (see below) obeys a similar mechanism.

\subsection{Effects of mAbs on Glu plasminogen binding to a fibrin sensor chip}

To test the effect of mAbs CPL15 and A10.2 on binding of plasminogen to the fibrin sensor chip, a concentration of $25 \mathrm{nmol} / \mathrm{l}$ of plasminogen was chosen from the binding isotherm shown in Fig. 2. This concentration produces a clearly measurable sensor response ( $\sim 18$ RU). Fig. 3, main graph, shows adsorption of plasminogen $-\mathrm{mAb}$ com- 


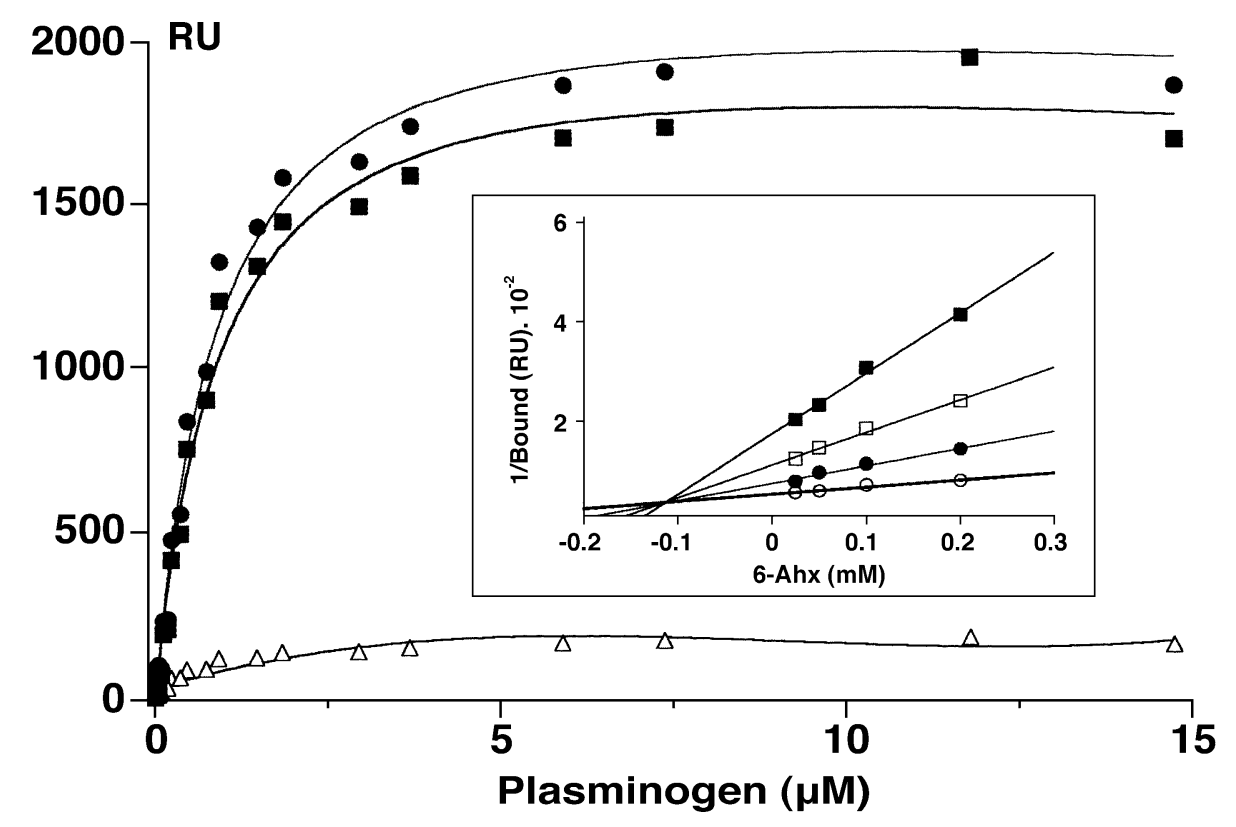

Fig. 2. Analysis of the binding of plasminogen to fibrin surfaces by SPR. Plasminogen was injected at the indicated concentrations over fibrin coated on glutaraldehyde-activated pioneer $\mathrm{C} 1$ sensor chips. The figure shows plots of RU values at varying plasminogen concentrations. $(\bullet)$ Total binding, $(\triangle)$ binding to an uncoated flow cell, ( $\mathbf{\square})$ specific binding. The solid lines represent the best nonlinear least square fit of the data to the rectangular hyperbolic binding equation (Eq. (2)). For this typical experiment, the calculated dissociation constant was: $K_{\mathrm{d}}=0.97 \mu \mathrm{M}$. Inset: Determination of the inhibition constant $\left(K_{\mathrm{i}}\right)$ of 6 Ahx on the binding of plasminogen to the fibrin sensor chip $(25 \mathrm{~nm}, \mathbf{\square} ; 46 \mathrm{nmol} / 1, \square ; 92 \mathrm{nmol} / 1, \mathbf{0} ; 184 \mathrm{nmol} / 1, O)$. The inhibition constant $\left(K_{\mathrm{i}}=0.112 \mathrm{mmol} / \mathrm{l}\right)$ was calculated at the intercept of the linear regression analysis of 1 /bound versus 6-Ahx concentration. Data points are the average of triplicate experiments.

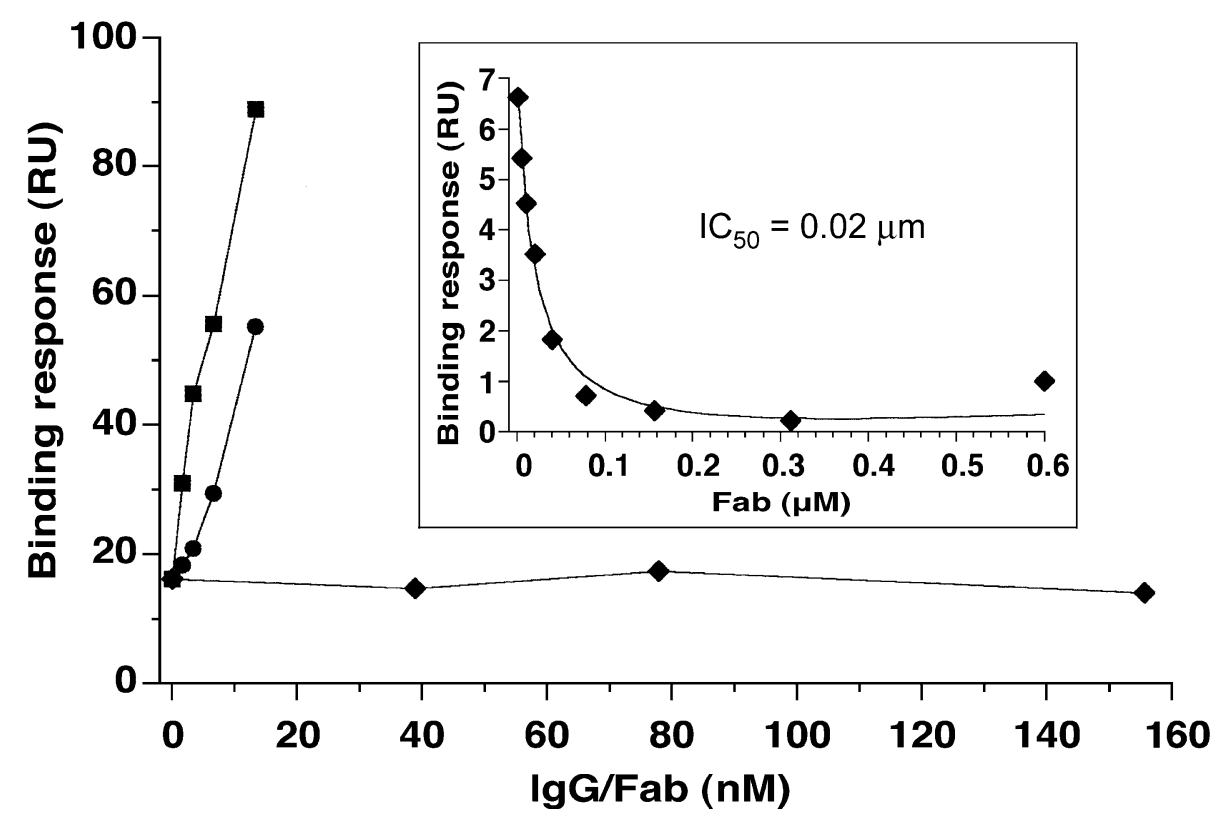

Fig. 3. SPR analysis of the effect of mAbs IgG or Fab on plasminogen binding to a fibrin sensor chip. Fibrin sensor surfaces were prepared as indicated in Materials and methods. Plasminogen $(25 \mathrm{nmol} / 1$, final concentration) was incubated with $\mathrm{mAbs}$ or Fab fragments at the indicated concentrations and was then

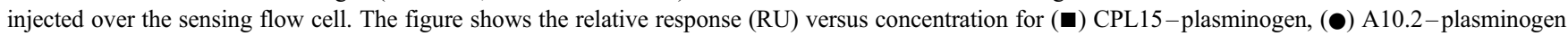
or $(\$)$ A10.2 Fab-plasminogen complexes. The response for the reference uncoated cell was subtracted from that of the fibrin-coated cell. Elution of plasminogen-mAbs complexes was performed with $200 \mathrm{mmol} / \mathrm{l}$ 6-Ahx. Inset. Analysis of r-apo(a) sensitivity to mAb A10.2 Fab fragment in binding to the fibrin sensor chip. RU values for r-apo(a) binding are plotted against the concentration of Fab. The solid line represents nonlinear analysis fitting of data points in terms of a hyperbolic decay relationship with the calculated parameter $\mathrm{IC}_{50}=0.02 \mu \mathrm{mol} / \mathrm{l}$, the concentration of Fab fragment that decreases by $50 \%$ the binding of r-apo(a) to the fibrin sensor chip. 
plexes as a function of mAb concentration. The data clearly show a linear relation between adsorption of the complexes and $\mathrm{mAb}$ concentration in the range studied. A control IgG had no effect on plasminogen binding to fibrin and injection of mAbs alone resulted in no detectable binding. The linear increase in plasminogen binding with $\mathrm{mAb}$ concentration suggests a bivalent binding model for the mAbs and the formation of plasminogen $-\mathrm{mAb}$ - plasminogen complexes. Therefore, to asses whether the promoter effect of mAbs on plasminogen binding to fibrin requires antibody bivalency, the effect of papain-derived mAb A10.2 FAb fragments on the binding of plasminogen to fibrin was studied. The Fab fragments were functionally active as indicated by their high affinity for plasminogen $\left(K_{\mathrm{d}}=3 \mathrm{nmol} / \mathrm{l}\right.$, data not shown) and their ability to inhibit apo(a) binding to fibrin (inset of Fig. 3 ) in a concentration-dependent manner $\left(\mathrm{IC}_{50}=0.02 \mu \mathrm{mol} /\right.$ 1). As shown in Fig. 3, Fab fragments did not promote plasminogen binding to the fibrin-coated sensor chip indicating that monovalent binding results in plasminogen-Fab complexes that do not promote enhancement of plasminogen binding.

If $\mathrm{mAb}$ bivalency is required for enhanced plasminogen binding, in excess of antibody, the interaction with the antigen may reach equivalency and promotion of binding should not occur. This hypothesis was explored by studying the effect of up to $250 \mathrm{nmol} / 1 \mathrm{CPL} 15$ on the binding of 25 nmol/1 plasminogen to the fibrin sensor chip. When CPL15 was flowed at concentrations between 0 and $250 \mathrm{nmol} / \mathrm{l}$, in the absence of plasminogen, no binding could be detected. Plasminogen at $25 \mathrm{nmol} / 1$ in the absence of CPL15 produced, as expected (Fig. 4), a response of $\sim 12 \mathrm{RU}$, that is, $\sim 0.13$ fmol of plasminogen bound per square millimeter of fibrin surface. At low $\mathrm{mAb}$ concentrations, $<2 \mathrm{nmol} / \mathrm{l}$, a linear response similar to that shown in Fig. 3 was obtained until a maximum ( $\sim 58 \mathrm{RU})$ was reached at a concentration of about $3 \mathrm{nmol} / 1 \mathrm{mAb}$ ( 5-fold increase over control IgG or plasminogen alone). However, at higher concentrations, the amount bound decreased progressively with increasing concentrations of mAb CPL15 until a plateau value similar to that of plasminogen alone was obtained. When the same mixtures of plasminogen and mAb were incubated with fibrin in a static system and the amount of plasminogen bound was detected by measuring the release of $\mathrm{pNa}$ from CBS 0065 in the presence of t-PA (see below), an identical bell-shaped profile was obtained (not shown). A control IgG did not significantly affect the binding of plasminogen to fibrin. The inset of Fig. 4 shows identical effects of $\mathrm{mAb}$ CPL15 on the binding of the plasminogen fragment kringle $1+2+3$ to fibrin. Altogether, these results indicate that the interaction of either plasminogen or its $\mathrm{K} 1+2+3$ fragment with mAb CPL15 follows a bivalent mechanism that explains the increase in plasminogen binding to fibrin.

\subsection{Effect of $m A$ bs on plasmin generation and fibrinolysis}

The model of a fibrin surface used in these experiments allows quantitation of plasmin generation by measuring either the progress of hydrolysis of a chromogenic substrate selective for plasmin or the radioactivity bound. Plasminogen $(150 \mathrm{nmol} / 1$ final concentration) containing $\sim 4$ to 8 $\mathrm{nmol} / 1$ radiolabelled plasminogen as a tracer, was activated by fibrin-bound $\mathrm{t}-\mathrm{Pa}$ in the presence of various concentra-

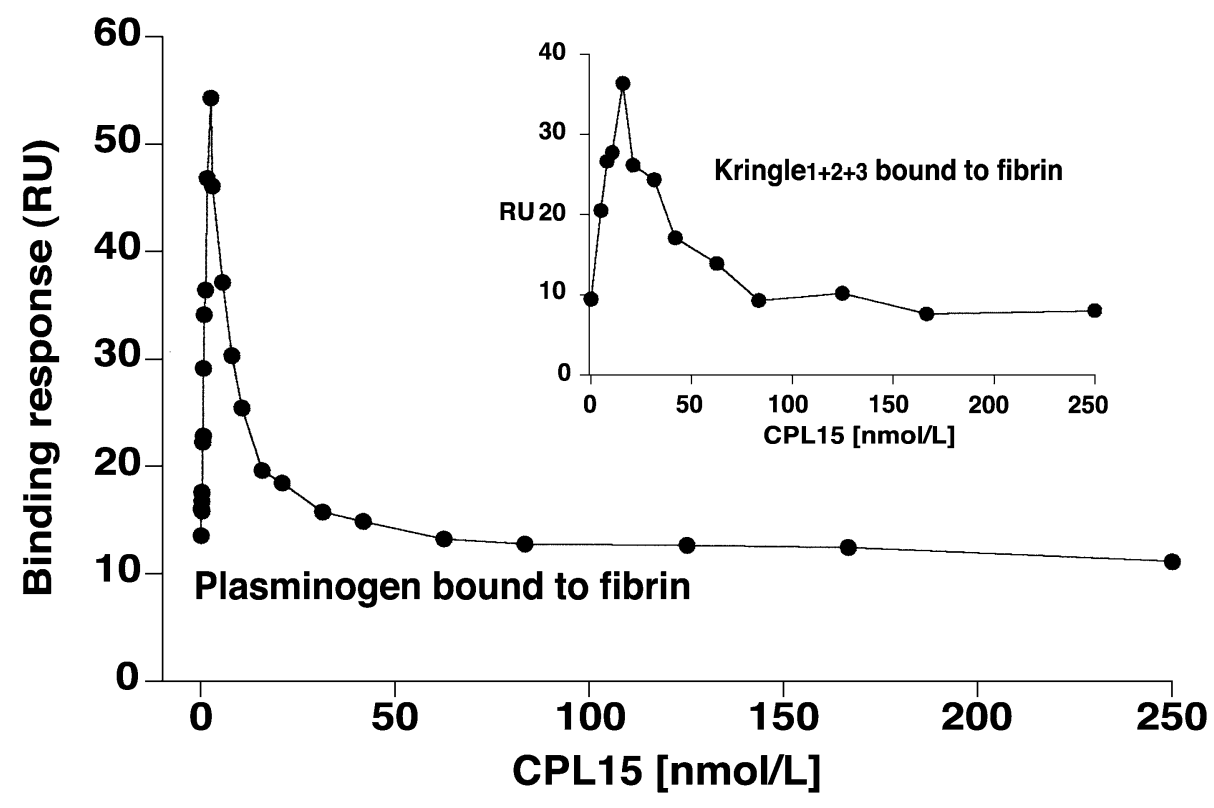

Fig. 4. SPR analysis of the effect of mAb CPL15 on binding of plasminogen to the fibrin sensor chip. MAb CPL15 and plasminogen at respectively $0-250$ and $25 \mathrm{nmol} / 1$ final concentrations were incubated for $30 \mathrm{~min}$ at room temperature. A volume of $10 \mu \mathrm{l}$ of each mixture was then injected over the fibrin sensor surface. The binding response is plotted versus the concentration of $\mathrm{mAb}$. Inset: Fibrin binding isotherm of plasminogen fragment $\mathrm{K} 1+2+3$ obtained by varying $\mathrm{mAb}(0-250 \mathrm{nmol} / \mathrm{l})$ at a fixed concentration of $\mathrm{K} 1+2+3(25 \mathrm{nmol} / \mathrm{l})$. Elution of plasminogen $-\mathrm{mAbs}$ complexes was performed with $0.2 \mathrm{~mol} / 1$ 6-Ahx. 
tions of either mAbs (CPL15, A10.2) $\mathrm{IgG}_{1}$ or Fab fragments. Controls included were a P3X63 myeloma IgG and a sample of plasminogen in buffer with no added $m A b$. The amount of plasmin generated at the surface of fibrin at each time point was detected at the end of the activation experiment. A linear increase in the amount of plasmin formed as a function of time was measured with both the chromogenic substrate assay (activity of plasmin) and by counting the radioactivity (mass of protein bound, Fig. 5). In all cases (controls, absence or presence of mAbs), the amount of plasmin formed at the surface of fibrin increased as a function of time throughout the activation period. However, the amount of plasmin generated in the presence of mAbs was significantly increased at the concentrations of 15 and $100 \mathrm{nmol} / 1$. Indeed, plasmin formation occurred at a 10-fold higher activation rate at a concentration of $100 \mathrm{nmol} / \mathrm{mAb}$ CPL15 or A10.2 (165 and $181 \mathrm{fmol} / \mathrm{min}$, respectively) than in the presence of the control $\operatorname{IgG}(26.4 \mathrm{fmol} / \mathrm{min})$. Of note that at a $\mathrm{mAb}$ concentration of $500 \mathrm{nmol} / \mathrm{l}$, the amount of plasmin formed was lower than in the presence of $15 \mathrm{nmol} / 1$ $\mathrm{mAb}$ and approached the control values. In contrast, the profile obtained at the different Fab fragment concentrations tested was in all cases similar to that obtained with controls (Fig. 6). The progressive increase in protein mass of plasmin(ogen) bound to fibrin during the activation experiments was parallel to the increase in plasmin activity as measured with the chromogenic substrate assay. Altogether, these results indicate that the increase in plasmin activity

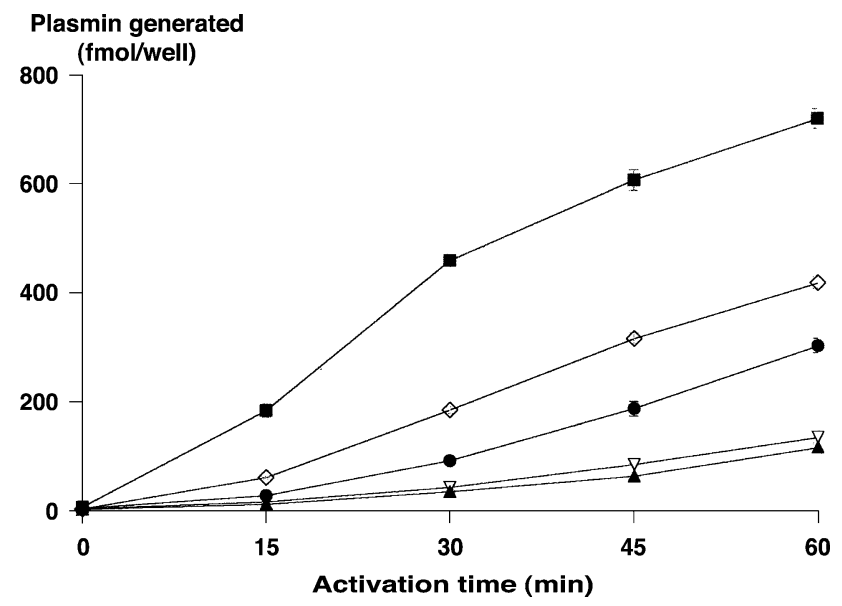

Fig. 5. Effect of CPL15 mAb on plasminogen activation at fibrin surfaces. Plasminogen activation experiments were performed under static conditions using fibrin surfaces incubated with t-Pa at $50 \mathrm{IU} / \mathrm{ml}$. Excess t-PA was discarded and the reaction was started by adding $50 \mu \mathrm{l}$ per well of the activation solution for the indicated times. The activation solution was purified plasminogen $(150 \mathrm{nmol} / \mathrm{l})$ supplemented with a trace amount $(4$ $\mathrm{nmol} / \mathrm{l}$ final concentration) of ${ }^{125}$ I-plasminogen in assay buffer $(\nabla)$ and one of the following mAb CPL15 at $(\diamond) 15 \mathrm{nmol} / 1$, (®) $100 \mathrm{nmol} / 1$ and $(\bullet) 500$ $\mathrm{nmol} / 1$, or non-immun P3X63 IgG at $(\boldsymbol{\Delta}) 100 \mathrm{nmol} / \mathrm{l}$. The time course of the activation was followed at regular intervals at $37{ }^{\circ} \mathrm{C}$. The wells were dried, cut off and the radioactivity counted in a $\gamma$-radiation counter. The bound radioactivity was converted into femtomoles of plasmin(ogen) bound per well as calculated from the molar radioactivity of the plasminogen input solution, and plotted versus the activation time.

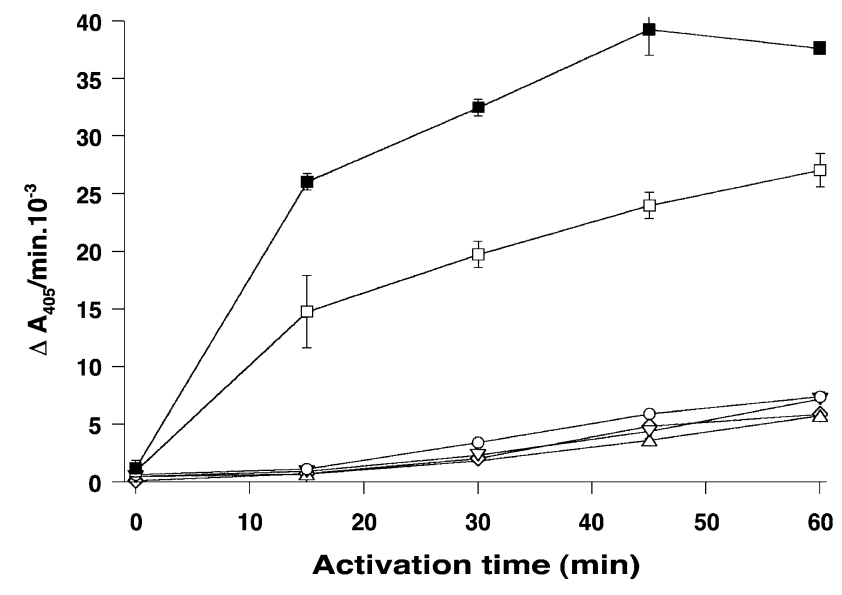

Fig. 6. Effect of mAb A10.2 IgG and Fab fragment on plasminogen activation by fibrin-bound t-PA. The procedure for activation was as described in Fig. 5. The activation mixture was assay buffer containing 150 nmol/1 Glu-plasminogen alone $(O)$ or supplemented with one of the following: Fab fragments at $15 \mathrm{nmol} / \mathrm{l}(\nabla)$, or $100 \mathrm{nmol} / \mathrm{l}(\triangle), \mathrm{mAb} \mathrm{A} 10.2$ at $15 \mathrm{nmol} / 1(\square)$ or non-immun $\operatorname{IgG}$ at $15 \mathrm{nmol} / 1(\diamond)$. The reaction was stopped by removing the fluid phase at the indicated times, and plasmin generated at the fibrin surface was measured by addition of $1.5 \mathrm{nmol} / \mathrm{l} \mathrm{CBS}$ 0065. The release of $p$-nitroaniline from the substrate was monitored at 37 ${ }^{\circ} \mathrm{C}$ in a microtitration plate counter at a double-wavelength absorbance ratio $\left(A_{405 / 490} \mathrm{~nm}\right)$. Initial velocities for each time point are given in $v=(\Delta 405 /$ min) $10^{3}$. Fibrin surfaces onto which plasminogen activation was performed in the presence of $15 \mathrm{nmol} / 1 \mathrm{mAb}$ A10.2 IgG (ם) were further probed with a goat anti-mouse horseradish peroxidase-labelled $\operatorname{IgG}(\square)$. Data points represent the average of duplicate determinations from three different experiments. Intra-assay and inter-assay coefficients of variation derived from measurements of plasmin activity were $2.5 \pm 0.1$ and $8.1 \pm 0.2$, respectively.

was due to an increase in the amount of plasminogen bound to the surface of fibrin.

\subsection{Detection of monoclonal antibodies at the fibrin surface}

In parallel experiments, after quantification of fibrinbound plasmin activity, the surface was probed with a peroxidase-labelled-goat-anti-mouse $\operatorname{IgG}$ at a proper dilution. Fig. 6 shows typical plasminogen activation kinetics in the presence of $\mathrm{mAb} A 10.2$. When this $\mathrm{mAb}$ was incubated with fibrin in the absence of plasminogen at concentrations identical to those used in the activation experiments, it did not bind to fibrin. In contrast, in the presence of plasminogen, the increase in plasmin formation over controls, at each time point during the activation process, was simultaneously associated with a progressive increase in binding of the $\mathrm{mAb}$.

\section{Discussion}

The purpose of these studies was to investigate the mechanism by which mAbs directed against plasminogen enhance the rate of plasmin formation at the surface of fibrin, that is, fibrinolysis. It has been reported that some 
mAbs directed against plasminogen kringles may induce 6Ahx-like conformational changes that increase the rate of plasmin formation [46-48]. However, mAbs may exert their effects on plasmin formation at surfaces through an other mechanism which is intrinsic to antibody structure: ligand bivalency. This possibility is evoked by studies with anti-phospholipid antibodies and their effect on thrombin production [16].

Thrombin production, the counterpart of surface-controlled plasmin formation, involves the clustering of phospholipid-binding proteins on activated platelets. Bivalent binding of anti-phospholipid antibodies can increase thrombin production through enhancement of prothrombin binding by formation of clusters [17,18]. A similar bivalent mechanism has been proposed for the anti-phospholipid antibody-induced enhanced binding of $\beta_{2}$-glycoprotein 1 to phospholipid surfaces [19-22]. Therefore, an alternative explanation to the conformational changes hypothesis on the enhancement of plasmin formation by mAbs would be enhanced plasminogen binding through antibody bivalency.

In the present work, we have evaluated this mechanism using mAbs directed against distinct domain of the plasminogen molecule: A10.2, a mAb that reacts with the LBS of kringle 4 [23], and CPL15, a mAb directed against plasminogen kringle 1 [24]. Affinities of these mAbs for plasminogen and the corresponding fragments were in the low nanomoles per liter range $\left(K_{\mathrm{d}}=10 \mathrm{nmol} / 1\right.$ for $\mathrm{A} 10.2$ and $K_{\mathrm{d}}=32 \mathrm{nmol} / 1$ for CPL15). We have explored the effect of these mAbs on the binding of plasminogen to well-characterised fibrin surfaces that support plasminogen binding and activation $[27,29]$. We have now developed the preparation of these fibrin surfaces in sensor chips for SPR studies. The immobilised fibrinogen was enzymatically digested on the sensor chip by delivering thrombin to the sensing flow cell, through the microfluidic system. After on-chip digestion, a fibrin surface was obtained that binds plasminogen and $\mathrm{r}$ apo(a) with affinities similar to those previously determined in other systems $\left(K_{\mathrm{d}} \sim 1 \mu \mathrm{mol} / 1\right.$ and $K_{\mathrm{d}} \sim 50 \mathrm{nmol} / \mathrm{l}$, respectively). The mAb A10.2 blocks the LBS of kringle 4 and behaves in that way as a lysine analogue. However, plasminogen contains a distinct LBS in kringle 1 that is not affected by mAb A10.2 and ensures its binding to fibrin. mAb CPL15 recognises a region in kringle 1 of plasminogen that does not interfere with its fibrin-binding function. Both mAb A10.2 and mAb CPL15 increased the rate of plasmin formation at the surface of fibrin in a concentrationdependent manner.

The possibility that this enhancing effect may be due to an increase in plasminogen binding was explored in the present work as follows. The assembly on plasminogen of fibrin in the presence of mAbs was studied by SPR under flow conditions. The kinetics of the formation of plasmin on fibrin surfaces was studied in parallel. The results of these studies demonstrate a parallel increase in both the mass of plasminogen bound and the enhancement of plasmin formation. Indeed, a linear increase in the binding of plasminogen to the fibrin surface was observed with increasing concentrations of the mAbs until a maximum was reached. This effect was immediately followed, at higher $\mathrm{mAb}$ concentrations, by a regression in the amount bound until a level similar to that observed in the absence of mAbs was reached. Because mAb CPL15 does not interfere with the fibrin-binding function of kringle 1, a similar bell-shaped isotherm could be obtained when the $\mathrm{K} 1+2+3$ plasminogen fragment was used. This effect could not be obtained with isolated plasminogen kringle 4 since mAb A10.2 inhibits its binding to fibrin by blocking its LBS.

We hypothesize (Fig. 7) that the bell-shaped isotherm was due to the formation of bivalent ternary and monovalent binary complexes at the varying plasminogen $/ \mathrm{mAb}$ ratios

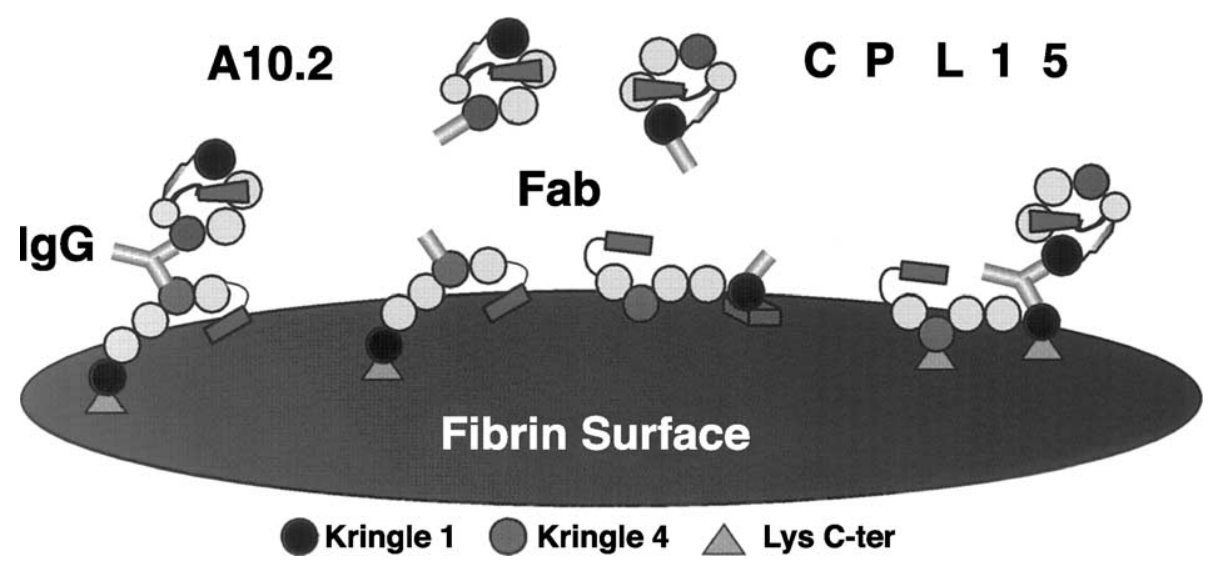

Fig. 7. Proposed bridging mechanism for mAb-induced increase in plasminogen binding to fibrin and plasmin formation. Plasminogen interacts with lysine residues in fibrin with dissociation constant, $K_{\mathrm{d}}=0.92 \mu \mathrm{mol} / \mathrm{l}$, and with mAbs directed against kringle 1 (CPL15, $\left.K_{\mathrm{d}}=5.8 \mathrm{nmol} / \mathrm{l}\right)$ and kringle 4 (A10.2, $\left.K_{\mathrm{d}}=5.6 \mathrm{nmol} / \mathrm{l}\right)$. According to experimental data in Figs. 3 and 4, bivalency of mAbs induces the formation of ternary complexes at high $\mathrm{mAb} / \mathrm{plasminogen}$ ratios (excess plasminogen, low $\mathrm{mAb}$ ) and increases thereby the amount of plasminogen bound to the surface of fibrin. A possible interpretation for this findings is that the mAbs may function as a bridge between one molecule of plasminogen bound to fibrin and another molecule of plasminogen in the soluble phase. Our data do not discard, however, the possibility that the two molecules of plasminogen engaged with one molecule of mAb in the formation of the ternary complex, may be bound to fibrin. 
studied, an effect not uncommon in antibody studies and most probably a consequence of antibody bivalency [49]. In the proposed model, at a fixed plasminogen concentration, the formation of plasminogen $-\mathrm{mAb}$-plasminogen ternary complexes able to bind to fibrin increases with the progressive increase in $\mathrm{mAb}$ concentration. The maximum concentration of ternary complexes formed, and therefore the maximal amount of plasminogen detected at the fibrin surface, is reached when the concentration of plasminogen and $\mathrm{mAb}$ attains equivalency. With further increases in the concentration of $\mathrm{mAb}$, the formation of ternary complexes is reduced and the interaction is shifted to the formation of plasminogen $-\mathrm{mAb}$ binary complexes which results in the observed decrease in the amount of plasminogen detected at the fibrin surface. As a matter of fact, mAbs were found at the fibrin surface in a concentration-dependent manner only in the presence of plasminogen. Bivalency of mAbs may therefore function as a bridge between two molecules of plasminogen, one molecule being bound directly to fibrin and the other in the fluid phase. To test this hyphothesis, Fab fragments were examined for their ability to promote plasminogen binding to fibrin. First, we demonstrated that the A10.2 Fab fragments were functionally active as indicated by their ability to inhibit apo(a) binding to fibrin $\left(\mathrm{IC}_{50}=20 \mathrm{nmol} / \mathrm{l}\right)$. No increase in the binding of plasminogen was observed with increasing concentrations of the Fab fragments, indicating that bivalency of mAbs was the operating mechanism required for enhanced plasminogen binding to fibrin.

The possibility that the bridging model may be operating with two molecules of plasminogen bound to fibrin (clustering) as in the prothrombin and $\beta_{2}$-glycoprotein 1 models $[18,20,22]$ cannot be ruled out. However, in that model, binding of the antibodies to different epitopes may result in complexes of various sizes and stoichiometries, and their low affinity (micromoles per liter range) for prothrombin may favor clustering. In contrast, in our fibrin binding model, the plasminogen $-\mathrm{mAb}$ interaction is of high affinity (nanomoles per liter range), monospecific by definition, and the low plasminogen density that may be obtained at the concentration used $(25 \mathrm{nmol} / \mathrm{l}, 40$-fold lower than its $\sim 1$ $\mu \mathrm{mol} / 1 K_{\mathrm{d}}$ for fibrin), may fail to promote plasminogen clustering. Furthermore, since the concentration of plasminogen bound to fibrin is governed by the affinity of the interaction, bivalency of the mAb toward two plasminogen molecules will not result in increased plasminogen binding. In agreement with these concepts, the bell-shaped isotherm was skewed to very low $\mathrm{mAb}$ concentrations indicating that (1) the affinity of $\mathrm{mAb}$ for plasminogen was the determinant factor in bringing supplementary molecules of plasminogen to the fibrin surface and (2) that this phenomenon was independent of the affinity of plasminogen for fibrin.

The bridging effect of mAbs on plasminogen is further substantiated by time course plasminogen activation experiments at the surface of fibrin. The kinetics of plasmin formation at the surface of fibrin was detected by measuring both the mass of plasmin formed and its amidolytic activity. The t-PA was first bound to the fibrin surface, a condition that may be equivalent to the binding of circulating t-PA to the surface of a clot. A mixture of mAbs and Glu-plasminogen was used for the activation experiments. The subsequent appearance of plasminogen derivatives and the binding of mAbs or Fab was determined as the fibrin was degraded. This experimental setup was similar to the one previously described to isolate the effect of $L p(a)$ on plasminogen activation [13], and offered the additional advantage to measure plasmin(ogen) and monoclonal antibodies on the same surface of fibrin using specific antibodies and a chromogenic substrate assay. As for plasminogen binding, the ability of mAbs to enhance plasmin formation was concentration dependent until a maximum was reached. At a high $\mathrm{mAb}$ concentration $(500 \mathrm{nmol} / \mathrm{l})$, the amount of plasmin formed decreased toward levels measured in the absence of mAbs.

Although our data underscore the importance of antibody bivalency, they do not exclude the possibility that mAb may induce conformational changes as well. However, such conformational changes are not required to explain the binding and kinetics of plasminogen activation. Indeed, if binding of mAbs to plasminogen was solely to induce conformational changes that increase the rate of plasmin formation, the interaction with Fab fragments should have been equivalent. The absence of role of Fab fragments indicates that the effect of $\mathrm{mAb}$ is mainly due to bivalency.

In conclusion, our data support a model (Fig. 7) for mAbs enhancement of plasminogen binding and plasmin formation in which $\mathrm{mAb}$ bivalency engages one molecule of plasminogen bound to fibrin and another plasminogen molecule from the fluid phase. This mechanism is different from the cross-linking clustering mechanism proposed for the enhancement of $\beta_{2}$-glycoprotein 1 binding by antiphospholipid antibodies.

\section{Acknowledgements}

Valuable help in the purification of monoclonal antibodies by S. Loyau is gratefully acknowledged. This work was supported by the Institut National de la Sante et de la Recherche Medicale and grant Adrienne et Pierre Sommer from the Fondation de France. M. Dominguez was a member of the ECOS M95B02 Program and was the recipient of a research scholarship from the Consejo Nacional de Ciencia y Tecnologia de Mexico.

\section{References}

[1] C.P. Ponting, J.M. Marshall, S.A. Cederholm-Williams, Plasminogen: a structural review, Blood Coagul. Fibrinolysis 3 (1992) 605-614.

[2] J.D. Vassali, A.-P. Sappino, D. Belin, The plasminogen activator/plasmin system, J. Clin. Invest. 88 (1991) 1067-1072.

[3] K.A. Hajjar, P.C. Harpel, E.A. Jaffe, R.L. Nachman, Binding of plas- 
minogen to cultured human endothelial cells, J. Biol. Chem. 261 (1986) 11656-11662.

[4] T. Herren, T.A. Burke, M. Jardi, J. Felez, E.F. Plow, Regulation of plasminogen binding to neutrophils, Blood 97 (2001) 1070-1078.

[5] J. Felez, Plasminogen binding to cell surfaces, Fibrinolysis Proteolysis 12 (1998) 183-189.

[6] L.A. Miles, E.F. Plow, Plasminogen receptors: ubiquitous sites for cellular regulation of fibrinolysis, Fibrinolysis 2 (1988) 61-71.

[7] L. Patthy, M. Trexler, Z. Vali, L. Banyai, A. Varadi, Kringles: modules specialized for protein binding, FEBS Lett. 171 (1984) 131-136.

[8] M. Hoylaerts, D.C. Rijken, H.R. Lijnen, D. Collen, Kinetics of the activation of plasminogen by human tissue plasminogen activator, J. Biol. Chem. 257 (1982) 2912-2919.

[9] V. Ellis, K. Dano, The urokinase receptor and the regulation of cell surface plasminogen activation, Fibrinolysis 6 (1992) 27-34.

[10] K. Berg, A new serum type system in the man, Acta Pathol. Microbiol. Scand. 59 (1963) 369-382.

[11] J.W. McLean, J.E. Tomlinson, W.J. Kuang, D.L. Eaton, E.Y. Chen, G.M. Fless, A.M. Scanu, R.M. Lawn, cDNA sequence of human apolipoprotein(a) is homologous to plasminogen, Nature 300 (1987) $132-137$.

[12] L. Hervio, V. Durlach, A. Girard-Globa, E. Angles-Cano, Multiple binding with identical linkage: a mechanism that explains the effect of lipoprotein(a) on fibrinolysis, Biochemistry 34 (1995) $13353-$ 13358.

[13] T. Soulat, S. Loyau, V. Baudouin, L. Maisonneuve, M.F. Hurtaud Roux, N. Schlegel, C. Loirat, E. Angles-Cano, Effect of individual plasma lipoprotein(a) variations in vivo on its competition with plasminogen for fibrin and cell binding - an in vitro study using plasma from children with idiopathic nephrotic syndrome, Arterioscler. Thromb. Vasc. Biol. 20 (2000) 575-584.

[14] G. Markus, J.L. Evers, G.H. Hobika, Comparison of some properties of native (Glu) and modified (Lys) human plasminogen, J. Biol. Chem. 253 (1978) 733-739.

[15] A.J.G. Horrevoets, A.E. Smilde, J.C. Fredenburgh, H. Panekoek, M.E. Nesheim, The activation resistant conformation of recombinant human plasminogen is stabilized by basic residues in the amino-terminal hinge region, J. Biol. Chem. 270 (1995) 15770-15776.

[16] L.V.M. Rao, A.D. Hoang, S.I. Rapaport, Mechanism and effects of the binding of lupus anticoagulant IgG and prothrombin to surface phospholipids, Blood 88 (1996) 4173-4182.

[17] S.L. Field, P.J. Hogg, E.B. Daly, Y.-P. Dai, B. Murray, D. Owens, C.N. Chesterman, Lupus anticoagulant form immune complexes with prothrombin and phospholipid that can augment thrombin production in flow, Blood 94 (1999) 3421-3431.

[18] S.L. Field, C.N. Chesterman, Y.-P. Dai, P.J. Hogg, Lupus antibody bivalency is required to enhance prothrombin binding to phospholipid, J. Immunol. 166 (2001) 6118-6125.

[19] R.A.S. Roubey, R.A. Eisenberg, M.F. Harper, J.B. Winfield, Anticardiolipin autoantibodies recognize b2-glycoprotein I in the absence of phospholipid. Importance of $\mathrm{Ag}$ density and bivalent binding, J. Immunol. 154 (1995) 954-960.

[20] G.M. Willems, M.P. Janssen, M.M.A.L. Pelsers, P. Comfurius, M. Galli, R.F.A. Zwaal, E.M. Bevers, Role of divalency in the highaffinity binding of anticardiolipin antibody-b2-glycoprotein complexes to lipid membranes, Biochemistry 35 (1996) 13833-13842.

[21] H. Takeya, T. Mori, E.C. Gabazza, K. Kuroda, H. Deguchi, E. Matsuura, K. Ichikawa, T. Koike, K. Suzuki, Anti-b2-glycoprotein I (b2GPI) monoclonal antibodies with lupus anticoagulant-like activity enhance the b2GPI binding to phospholipids, J. Clin. Invest. 99 (1997) $2260-2268$.

[22] J. Arnout, C. Wittevrongel, M. Vanrusselt, M. Hoylaerts, J. Vermylen, Beta-2-glycoprotein I dependent lupus anticoagulants form stable bivalent antibody beta-2-glycoprotein I complexes on phospholipid surfaces, Thromb. Haemost. 79 (1998) 79-86.

[23] M. Dominguez, G. Rojas, S. Loyau, M. Bazurco, L. Sorell, E. AnglesCano, Kringles of the plasminogen-prothrombin gene family share conformational epitopes with recombinant apo(a). Specificity of the fibrin-binding site, Biochim. Biophys. Acta 1548 (2001) 72-80.

[24] R. Montes, J.A. Paramo, E. Angles-Cano, E. Rocha, Development and clinical application of a new ELISA assay to determine plasminalpha2-antiplasmin complexes in plasma, Br. J. Haematol. 92 (1996) 979-985.

[25] L.A. Kazal, S. Amsel, O.P. Miller, L.M. Tocantis, The preparation and some properties of fibrinogen precipitated from human plasma by glycine, Proc. Soc. Exp. Biol. Med. 113 (1963) 989-994.

[26] P. Grailhe, C. Boyer-Neumann, F. Haverkate, J. Grimbergen, M.J. Larrieu, E. Angles-Cano, The mutation in fibrinogen Bicetre II (gamma Asn308 $\rightarrow$ Lys) does not affect the binding of t-PA and plasminogen to fibrin, Blood Coagul. Fibrinolysis 4 (1993) 679-687.

[27] V. Fleury, E. Angles-Cano, Characterization of the binding of plasminogen to fibrin surfaces: the role of carboxy-terminal lysines, Biochemistry 30 (1991) 7630-7638

[28] L. Sottrup-Jensen, H. Claeys, M. Zajdel, T.E. Petersen, S. Magnusson, The primary structure of human plasminogen: isolation of two lysinebinding fragments and one "mini-"plasminogen (MW, 38,000) by elastase-catalyzed-specific limited proteolysis, Progress Chem. Fibrinolysis Thrombolysis 3 (1978) 191-209.

[29] D. Rouy, M.L. Koschinsky, V. Fleury, J. Chapman, E. Angles-Cano, Apolipoprotein(a) and plasminogen interactions with fibrin: a study with recombinant apolipoprotein(a) and isolated plasminogen fragments, Biochemistry 31 (1992) 6333-6339.

[30] A. Bezeaud, M.H. Denninger, M.C. Guillin, Interaction of human alpha-thrombin and gamma-thrombin with antithrombin III, protein C and thrombomodulin, Eur. J. Biochem. 153 (1985) 491-496.

[31] B. Blombäck, M. Blombäck, Purification of human and bovine fibrinogen, Ark. Kemi. 10 (1956) 415-433.

[32] P. Wallen, B. Wiman, Characterization of human plasminogen: II. Separation and partial characterization of different molecular forms of human plasminogen, Biochim. Biophys. Acta 257 (1972) 122-134.

[33] J.W. Fenton II, M.J. Fasco, A.B. Stackrow, Human thrombins production, evaluation, and properties of $\alpha$-thrombin, J. Biol. Chem. 252 (1977) 3587-3598.

[34] P.J. Fraker, J.C. Speck, Protein and cell membrane iodinations with a sparingly soluble chloramide, 1,3,4,6, tetrachloro-3a-6a diphenyl glycoluril, Biochem. Biophy. Res. Commun. 80 (1978) 849-857.

[35] P.W. Koppert, C.M.G. Huijsmans, W. Nieuwenhuizen, A monoclonal antibody, specific for human fibrinogen, fibrinopeptide A-containing fragments and not reacting with free fibrinopeptide A, Blood 66 (1985) 503-507.

[36] P.L. Ey, S.J. Prowse, C.R. Jenkin, Isolation of pure IgG1, IgG2a and IgG2b immunoglobulins from mouse serum using protein A Sepharose, Immunochemistry 15 (1978) 429-436.

[37] U. Jonsson, L. Fagerstam, B. Ivarsson, B. Johnsson, R. Karlsson, K. Lundh, S. Lofas, B. Persson, H. Roos, I. Ronnberg, Real-time biospecific interaction analysis using surface plasmon resonance and a sensor chip technology, BioTechniques 11 (1991) 620-627.

[38] E. Stenberg, B. Persson, H. Roos, C. Urbaniczky, Quantitative determination of surface concentration of protein with surface plasmon resonance using radiolabeled proteins, J. Colloid Interface Sci. 143 (1991) 513-526.

[39] R. Karlsson, A. Michaelsson, L. Mattsson, Kinetic analysis of monoclonal antibody-antigen interactions with a new biosensor based analytical system, J. Immunol. Methods 145 (1991) 229-240.

[40] D. Rouy, E. Angles-Cano, The mechanism of activation of plasminogen at the fibrin surface by tissue-type plasminogen activator in a plasma milieu in vitro. Role of alpha 2-antiplasmin, Biochem. J. 271 (1990) 51-57.

[41] V. Fleury, V. Gurewich, E. Angles-Cano, A study of the activation of fibrin-bound plasminogen by tissue-type plasminogen activator, single chain urokinase and sequential combinations of the activators, Fibrinolysis 7 (1993) 87-96.

[42] A.W. Adamson, Physical Chemistry of Surfaces: The Langmuir Adsorption Isotherm, 5th edn., Wiley, New York, 1990, pp. 595-605. 
[43] P. Shuck, A.P. Minton, Kinetic analysis of biosensor data: elementary test for self-consistency, Trends Biochem. Sci. 252 (1996) 458-460.

[44] R. Karlsson, L. Fagerstam, H. Nilshans, B. Persson, Analysis of active antibody concentration. Separation of affinity and concentration parameters, J. Immunol. Methods 166 (1993) 75-84.

[45] D.G. Myszka, Kinetic analysis of macromolecular interactions using surface plasmon resonance biosensors, Curr. Opin. Biotechnol. 8 (1997) 50-57.

[46] M. Mirshahi, J. Soria, H.R. Lijnen, V. Fleury, O. Bertrand, L. Drouet, J.P. Caen, C. Soria, A monoclonal antibody directed against an epitope in the NH2-terminal region of native human plasminogen induces a modification of its functional properties, Fibrinolysis Proteolysis 11 (1997) $155-163$.
[47] H.S. Cummings, F.J. Castellino, A monoclonal antibody to the aminocaproic acid binding site on the kringle 4 region of human plasminogen that accelerates the activation of Glu Plasminogen by urokinase, Arch. Biochim. Biophys. 236 (1985) 612-618.

[48] S. Madoiwa, K. Arai, Y. Ueda, M. Ishizuka, J. Mimuro, S. Asakura, M. Matsuda, Y. Sakata, A battery of monoclonal antibodies that induce unique conformations to evolve cryptic but constitutive functions of plasminogen, J. Biochem. 121 (1997) 278-287.

[49] P.J. Hogg, P.E.B. Reilly, D.J. Winzor, Consequences of ligand bivalency in interactions involving particulate receptors: equilibrium and kinetic studies with Sephadex-concanavalin A, butylagarose-phosphorylase $\mathrm{b}$, and $\mathrm{Fc}$ receptor- $\mathrm{IgG}$ dimer interactions as model systems, Biochemistry 26 (1987) 1867-1873. 